\title{
Possessive Adjectives Formed from Personal Names in Polish Translations of the New Testament
}

Adjectives denoting possession are formed from bases which indicate the possessor of an object expressed by the modified noun, for instance Jankowy rower, siostrzana mitość. Analyses of word formation in contemporary Polish demonstrate that this type of adjectives is going out of use. In fact, it is the constructions with the genitive (like rower Janka) that are taking over the role of possessive adjectives in present-day Polish ${ }^{1}$. It is common knowledge that the category of interest here was especially common in the Old Church Slavonic language, which is visible if we take a closer look at the monuments of the culture of Saint Cyril and Methodius $^{2}$. Moreover, Old Polish texts contain a high number of possessive adjectives (Ksieggi Mojzeszowy, z Adamowa boku - Sarospatak Bible). The phenomenon of possessive adjectives formed from proper names going out of use in the Polish language emerged between the $16^{\text {th }}$ and $18^{\text {th }}$ century and intensified from the middle of the $18^{\text {th }}$ century onwards ${ }^{3}$.

Possessive adjectives derived from personal names, formed by means of the suffixes -ow $(y)<{ }^{*}-o v b-j b$, -in//-yn $<{ }^{*}-i n z,-s k(i)<{ }^{*}-b s k b-j b$ inherited into Polish from Proto-Slavic, unambiguously denoted possession. On the contrary, derivatives of common nouns formed with suffixes generally signalling possessiveness could at times have a divergent semantic interpretation, e.g. lisi ogon 'tail belonging to a fox' (possessive adjective), but lisie spojrzenie 'look characteristic of a fox' (adjective denoting similarity $)^{4}$.

The word formation of possessive adjectives has been described exhaustively ${ }^{5}$. Adjectives formed from personal names at one point constituted such sizeable semantically homogenous groups of words that Krystyna Kleszczowa decided not to

1 R. Grzegorczykowa, Zarys stowotwórstwa polskiego, Warszawa 1984, p. 68.

2 Compare the frequent use of possessive adjectives formed from personal names in the Psalterium Sinaiticum, e.g. avraaml'b, aronovó, zaxarijinz (cf. T. FrIEdELówna, Biblijna onomastyka w staro-cerkiewno-stowiańskim Psałterzu synajskim, AUNC.FP 40(246), 1993, p. 3-25 (17-19).

3 S. Szlifersztejnowa, Przymiotniki dzierżawcze w jezzku polskim, Wrocław 1960, p. 40-41.

4 Z. Klemensiewicz, T. Lehr-Sp£awiński, S. Urbańczyк, Gramatyka historyczna języka polskiego, Warszawa 1981, p. 226-234.

5 Ibidem, p. 226-236; S. Szlifersztejnowa, op. cit. 
analyse them in her monograph on word formation of adjectival derivatives in Old Polish $^{6}$. It is essential for the evolution of the Polish system of word formation that the group of derivatives discussed here has almost gone out of use $\mathrm{e}^{7}$.

In the course of the work on anthroponymy in the Polish translations of the New Testament ${ }^{8}$ it turned out that possessive adjectives formed from proper names were not merely a broad category in Middle Polish translations, but also that their usage in particular texts depended on some factors which determine the linguistic shape of the translations. The factors in question are extralinguistic, such as the basis of the translation (Greek original or Latin Vulgate), the selection of methods and techniques of translation and the attitude to the tradition of translation'. Even a cursory look at the possessive adjectives points to the conclusion that the usage of this type of adjectives in translated texts may be conditioned by stylistic factors. Furthermore, whether or not to use a deanthroponymic possessive adjective was determined by purely linguistic factors; it depended on the phonetic shape of the anthroponym or its morphological structure. Considering all the circumstances that can affect the use of possessive adjectives derived from anthroponyms in the translations of the New Testament mentioned above, this type of derivatives should clearly be analysed linguistically.

The aim of this article is to take a closer look at possessive adjectives formed from personal names in the Polish translations of the New Testament ${ }^{10}$. We will focus on the old translations, i.e. those stemming from the $16^{\text {th }}$ and $17^{\text {th }}$ century, while keeping track of the latest, contemporary ones at the same time. The latter, for the most part, are in accordance with the developmental trends of contemporary Polish with reference to the category of adjectives in question. However, even these texts contain some possessive adjectives. This phenomenon is to be linked with

the rule of respect for linguistic custom, the tradition of the biblical Polish language, which causes the persistence of many invariant linguistic formulae in contemporary translations [...] and the stability of the biblical vocabulary ${ }^{11}$

as well as the invariability of some already archaic grammatical forms.

The study shows that the word formation structure of the forms under analysis is of paramount importance, but so are the factors which determine the linguistic shape and the use of the derivatives examined. What is of interest to us is the role of the extralinguistic factors mentioned above in the process of using

6 K. KLEszczowa, Staropolskie derywaty przymiotnikowe i ich perspektywiczna ewolucja, Katowice 2003, p. 62-63, p. $75-79$.

7 Possessive adjectives formed from personal names are still quite robust in the modern dialects.

8 R. ZAR̨̨BSKI, Stownik nazw osobowych w polskich przekładach Nowego Testamentu, Łódź 2005; IDEM, Nazwy osobowe w polskich przekładach Nowego Testamentu, Łódź 2006.

9 D. Bieńkowska, Polski styl biblijny, Łódź 2002, p. 24-33.

10 Cf. Sources, an. 12.

11 D. BieńkowsKa, op. cit., p. 144. 
possessive adjectives where the basic texts (Greek original or Latin Vulgate) display the substantival form of the name. We are thus touching upon the issue of choosing linguistic means of expression in a text; at the same time we are encroaching on the field of stylistics. We will try to show what impact using or not using possessive adjectives has on the stylistic layer of the translations excerpted.

Fifteen full and eleven incomplete translations of the New Testament into Polish have been examined. Among the former there are Middle Polish texts ${ }^{12}$ dating

${ }_{12}$ Cf. Sources in the list below:

B Biblia to jest Ksiegri starego i Nowego Przymierza [Ksiegi Nowego Przymierza Kto pospolicie Nowym Testamentem zowa $z$ wielka praca y pilnym poprawieniem $z$ Greckiego na Polski ięzyk przetlumaczone], trans. S. Budny, Nieśwież 1571-1572, ed. H. Rothe, F. ScholZ, repr. Paderborn-München-Wien-Zürich 1994 [= Biblia Slavica. $2^{\text {nd }}$ Series: Polnische Bibeln] (viz Biblia nieświeska or Nieśwież/Budny Bible).

Br Ewangelia wedlug Świętego Mateusza, trans. R. Brandstaetter, Warszawa 1986; Ewangelia według Świętego Marka, trans. IDEM, Warszawa 1980; Ewangelia według Świętego Łukasza, trans. IDEM, Warszawa 1982; Pisma Świętego Jana Ewangelisty. Ewangelia. Listy. Apokalipsa, trans. IDEM, Warszawa 1978; Święty Łukasz Ewangelista, Dzieje Apostolskie, trans. IDEM, Warszawa 1984.

Brz Biblia święta, to jest księgi Starego i Nowego Zakonu właśnie z żydowskiego, greckiego i łacińnkiego nowo na język polski z pilnościa i wiernie wyłożone..., Brześć Litewski 1563 (viz Biblia brzeska or Brześć Bible).

BT Pismo Święte Starego i Nowego Testamentu w przekładzie z języków oryginalnych, ed. coll. (on the initiative of the Benedictines of Tyniec), ${ }^{4}$ Poznan 1996, ( $\left.{ }^{1} 1965\right)$, (viz Biblia Tysiaclecia).

Cz Nowy Testament, to jest wszystkie pisma Nowego Przymierza z greckiego języka na rzecz polska wiernie i szczerze przełożone..., trans. M. Czechowic, Raków 1577.

D Nowy Testament. Nowy przekład z języka greckiego na wspótczesny język polski, Brytyjskie i Zagraniczne Towarzystwo Biblijne, Warszawa 1991.

Db Pismo święte Nowego Testamentu. Wstęp, nowy przekład $z$ Wulgaty. Komentarz, trans. E. DĄBrowsKI, ${ }^{7}$ Poznań-Warszawa-Lublin 1958 and Ewangelie i Dzieje Apostolskie, Wstęp. Nowy przekład $z$ Wulgaty. Komentarz, trans. IDEM, Poznań-Warszawa-Lublin 1953 ( $\left.{ }^{1} 1947\right)$.

Dn Dobra Nowina wedlug Mateusza i Marka, trans. W. Witwicki, Warszawa 1958.

E Ewangelia św. Mateusza. Przekład ekumeniczny, Warszawa 1997; Ewangelia św. Marka. Przekład ekumeniczny, Warszawa 1997; Ewangelia według św. Łukasza. Przekład ekumeniczny na język wspótczesny, Warszawa 2000; Pismo święte Nowego Testamentu i Psalmy. Przekład ekumeniczny z języków oryginalnych, Towarzystwo Biblijne w Polsce, Warszawa 2001.

G Biblia święta, to jest księgi Starego i Nowego Przymierza z żydowskiego i greckiego języka na polski pilnie i wiernie przettumaczone, Gdańsk 1632 (viz Biblia gdańska or Gdańsk Bible).

$H$ Harmonia ewangeliczna ( $15^{\text {th }} / 16^{\text {th }}$ century), [in:] S. VRTEL-WIERCZYŃsKI, Wybór tekstów staropolskich, Warszawa 1969.

I Grecko-polski Nowy Testament. Wydanie interlinearne z kodami gramatycznymi, trans. R. Popowski, M. Wojciechowski, Warszawa 1993.

K Pismo Święte Nowego Testamentu, trans. S. Kowalski, Warszawa 1978 (1957).

L Biblia to jest księgi Starego i Nowego zakonu na polski język z pilnością według łacińskiej Biblii, od Kościoła krześcijańskiego powszechnie przyjętej, nowo wyłożona..., Kraków 1561, (viz Biblia Leopolity or Leopolita Bible).

M Apokalipsa, trans. Cz. Mıєosz Cz. Mıєosz, Kraków 1998; Ewangelia wedlug Marka, Apokalipsa, trans. IDEM, Lublin 1989.

Mu Nowy Testament zupełny. Z greckiego języka na polski przełożony i wykładem krótkim objaśniony..., trans. S. Murzynowski, ed. J. Seklucjan, Królewiec Pruski 1553.

P Pismo Święte Starego i Nowego Testamentu w przekładzie z języków oryginalnych ze wstępami i komen- 
back to $16^{\text {th }}$ century $(M u, S z, L, B r z, B, C z, W), 17^{\text {th }}$ century $(G)$ and newer ones, from the $20^{\text {th }}$ century $(B T, P, P r, K, D, I, E)$. The incomplete ones are mostly contemporary translations $(D b, D n, B r, M)$, but they also include old ones from the $15^{\text {th }}$ and $16^{\text {th }}$ century $(H, Z b)$. The translations excerpted differ not only with respect to the chronological order, but also the basis of translation. $M u, B r z, B, C z, G, B T$, $D n, P, P r, K, B r, M, D, I, E$ were translated from the original languages, whereas $H$, $Z b, S z, L, W, D b$ are based on the Vulgate. Furthermore, the texts display divergent methods of translation. Some of them represent loose translations $(L)$, while others follow the original extremely closely (verbum de verbo) $(B, W)$. There are also philological $(B T)$, interlinear $(I)$, ecumenical $(E)$ and artistic $(M, B r)$ translations, as well as ones representing the technique of dynamic equivalence (formal equivalence) $(D)$. Such an extensive and varied collection of translations of a single text (in this case, the New Testament) allows for a complete and objective philological look not only at the New Testament names, but also at the possessive adjectives formed from anthroponymic bases.

As has been mentioned, possessiveness in older Polish was often expressed by means of possessive adjectives. In the $15^{\text {th }}-17^{\text {th }}$ century New Testament translations excerpted there are a great many adjectives formed from personal names. Numerous adjectives formed from masculine anthroponyms with the suffix -ow $(y)$ occur. If they appear in the form of nom. sg. in old texts $\left(15^{\text {th }}-17^{\text {th }}\right.$ century), they follow the short inflection; in the oblique cases they inflect according to the pronominal declension.

The following forms are only attested with the short inflection ${ }^{13}$ : Addow (<Addi), Apollow (<Apollo), Barnabaszow (<Barnabasz), Elmadanow (<Elmadan), Jonas $(z)$ ow $(<$ Jonasz), Jonow $(<$ Jona), Jazonow (< Jazon), Jeseow $(<$ Jesse), Jesow $(<$ Jese), Joseow ( $<$ Jose), Jonamow ( $<$ Jonam), Joramow ( $<$ Joram), Jowiszow $(<$ Jowisz), Judaszow $(<$ Judasz), Kajfaszow// Kajafaszow (< Kajfasz// Kajafasz), Kastorow (< Kastor), Kefasow (<Kefas), Lamechow (<Lamech), Matatyjaszow (<Matatyjasz), Melchijow (<Melchi), Molochow (< Moloch), Naggow//Naggeow (< Nag(g)e), Neryjow ( $<$ Neri), Pirrow ( $<$ Pirr), Publijuszow// Poplijow (<Publijusz), Salow// Saleow (<Sala), Semejow (<Semej), Ste-

tarzami, trans. M. Peter (ST), M. Wolniewicz (NT), vol. III, ${ }^{2}$ Poznań 1987 ( $\left.{ }^{1} 1974-1975\right)$ (viz Biblia poznańska or Poznań Bible).

Pr Biblia to jest Pismo Święte Starego i Nowego Testamentu. Nowy przekład z języków hebrajskiego i greckiego opracowany przez Komisję przekładu Pisma Świętego, Warszawa 1975.

Sz Nowy Testament polskim językiem wyłożony według doświadczonego łacińskiego tekstu od Kościoła krześcijańskiego przyjętego..., ed. M. SzarfFenBerg, Kraków 1556.

W Nowy Testament w przekładzie ks. dr. Jakuba Wujka z roku 1593, trans. J. WujeK, ed. W. SMereKA, Polskie Towarzystwo Teologiczne, Kraków 1966.

Zb Apokalipsa Św. Jana w przekładzie Tomasza ze Zbrudzewa (1555), ed. I. KwILECKA, WrocławWarszawa-Kraków-Gdańsk 1976.

13 All examples transcribed. 
fanow (<Stefan), Tymeuszow// Tymeow $\left(<\right.$ Tymeusz) ${ }^{14}$. Conversely, the following derivatives only followed the long inflection: Aaronowy (<Aaron), Abelowy// Ablowy (<Abel), Abijaszowy// Abijowy (< Abijasz), Aleksandrowy (< Aleksander), Appijuszowy// Appijowy (<Appijusz), Arstobulowy (<Arystobul), Arystobulusowy (<Arystobulus), Arystobulosowy ( $<$ Arystobulos), Asserowy ( $<$ Asser), Barachijaszowy ( $<$ Barachijasz), Barachijowy ( $<$ Barachija), Benijaminowy $(<$ Benijamin), Bosorowy $(<$ Bosor), Eberowy $(<$ Eber), Elijaszowy (< Elijasz), Ezajaszowy (< Ezajasz), Feliksowy ( $<$ Feliks), Festusowy// Festowy (< Festus), Gadowy (< Gad), Gamalijelowy (< Gamalijel), Herodowy (< Herod), Isacharowy (< Isachar), Izajaszowy (< Izajasz), Izraelowy (< Izrael), Jesajowy (< Jesaj), Jobowy $(<$ Job), Jonanowy (< Jonan), Josesowy $(<$ Joses), Kainanowy $(<$ Kain), Kefasowy $(<$ Kefas), Kisowy ( $<$ Kis), Kleofasowy ( $<$ Kleofas), Koreowy ( $<$ Kore), Manassesowy ( $<$ Manasses), Melchisedechowy (< Melchisedech), Narcysowy// Narkissowy (< Narcys), Neftalimowy ( $<$ Neftali), Piłatowy (< Piłat), Rubenowy ( $<$ Ruben), Rufowy $(<$ Ruf), Salaowy ( $<$ Sala), Salomonowy (< Salomonowy), Saulowy (<Saul), Szczepanowy (< Szczepan), Tytusowy $(<$ Tytus), Tytowy $(<$ Tyt), Urijaszowy $(<$ Urijasz), Zabulonowy ( $<$ Zabulon).

The rest of deanthroponymic adjectival forms use both the short and the long inflection: Abrahamow, $-y(<$ Abraham $)$, Adamow, $-y(<$ Adam $)$, Aminadabow, $-y(<$ Aminadab), Alfeuszow, -y/l Alfeow (<Alfeusz), Amosow, $-y$ (<Amos), Andrzejow, $-y(<A n-$ drzej), Apollosow, -y (<Apollos), Aramow, $-y$ (<Aram), Arfaksadow, $-y / /$ Arfakadowy (<Arfaksad), Boozow, $-y(<$ Booz), Dawidow, $-y$ (<Dawid), Elijakimow, $-y(<$ Elijakim), Elijezerow, $-y(<$ Elijezer), Enochow, $-y(<$ Enoch), Enosow, $-y(<$ Enos), Esromow, $-y(<$ Esrom), Falegow, $-y / /$ Falekowy (<Faklek), Faresow, $-y(<$ Fares), Heberow, $-y(<$ Heber), Herow, $-y$ $(<$ Her), Izaakow, $-y$ (< Izaak), Jakobow, $-y(<$ Jakub), Janow, $-y(<$ Jan), Jaretow// Jaredow, $-y(<$ Jaret $)$, Jezusow, $-y(<$ Jezus), Johanow, $-y(<$ Johan $)$, Jorymow, $-y(<$ Jorym), Jozefow, $-y$ (<Jozef), Judow, $-y(<$ Juda), Kosamow, $-y(<$ Kosam), Lewijow, $-y(<$ Lewi), Maatow, $-y$ (<Maat), Mahatow, $-y$ (<Mahat), Maleleelow, $-y$ (<Maleleel), Matatyjow, $-y$ (<Matatyja), Matatow, $-y$ (<Matat), Matusalow, $-y$ (<Matusala), Melchow, $-y(<$ Melcha), Meleow, $-y$ (<Melea), Mennow, $-y$ (<Menna), Mojżeszow, $-y(<$ Mojżesz), $\mathrm{Na}(a)$ s(s)onow, $-y(<\mathrm{Na}(a)$ $s(s)$ on), Nachorow, $-y(<$ Nachor), Natanow, $-y(<$ Natan), Naumow, $-y(<$ Naum), Obedow, $-y$ (< Obed), Onezyforow, $-y$ (< Onezyfor), Pawłow, $-y$ (<Pawet), Piotrow, $-y(<$ Piotr), Ragawow, $-y(<$ Ragaw), Ragamow, $-y(<$ Ragam), Resow, $-y(<$ Resa), Salatyjelow, $-y(<$ Salatyjel), Salmonow, $-y$ (<Salmon), Saruchow, $-y(<$ Saruch), Semow, $-y(<$ Sem), Setow, $-y(<$ Set $)$, Symeonow, $-y$ (<Symeon), Szymonow, $-y$ (<Szymon), Zacharyjaszow, $-y$ ( $<$ Zacharyjasz), Zebedeuszow, $-y / /$ Zebedeowy ( $<$ Zebedeusz), Zorobabelow, $-y(<$ Zorobabel).

The origin of the suffix -ow is connected with the forms of the gen. pl. of the Proto-Slavic $u$-stem declension. Adjectival derivatives in -ow were formed from masculine nouns and mostly denoted possession. They functioned as predicative attributes, which certainly contributed to their popularity in older Pol$\mathrm{ish}^{15}$. As can be seen from the material quoted above, they constituted a broad

14 The exact location cf. R. ZARĘBSKI, Stownik...

15 J. Łoś, Gramatyka polska, pars 2, Słowotwórstwo, Lwów-Warszawa-Kraków 1925, p. 23; S. SzLIFERSZTEJNOWA, op. cit., p. 85-89. 
category in the Old Polish and Middle Polish translations of the New Testament. In contemporary translations, genitival forms are used in place of adjectives functioning as attributes, which, as has already been said, is in accordance with the evolutionary trends of Polish. A simple comparison of a text from the $16^{\text {th }}$ century $(W)$ with a translation from the $20^{\text {th }}$ century $(B T)$ clearly shows that possessive adjectives disappear, giving way to genitival forms, e.g. żona Uriaszowa - żona Uriasza (Mt 1, 6), do śmierci Herodowej - do śmierci Heroda (Mt 2, 15), córka Fanuelowa - córka Fanuela $(\operatorname{Lc} 2,36)^{16}$. It is evident that the scale of this phenomenon is considerable. In the texts which form the basis of the translation (Greek original or Latin Vulgate), genitival forms occur where the older translations had possessive adjectives. That the translators of these texts used adjectival derivatives indicates the high degree to which the base antroponyms were morphologically adapted to Polish.

Thanks to the processes of adaptation, names of foreign origin entered various declensional types of Polish ${ }^{17}$. Among the examples mentioned there are derivatives formed from masculine personal names which belong to different declensions: masculine non-palatal, e.g. Elmadan > Elmadanow, Gad > Gadowy, Feliks > Feliksowy, Obed > Obedow, Tyt > Tytowy; masculine palatal, e.g. Judasz > Judaszow, Mojżesz > Mojżeszow(y); feminine vocalic, e.g. Abija > Abijowy, Juda > Judow(y), Matusala > Matusalow (y) and pronominal-adjectival, e.g. Addi $>$ Addow, Jese $>$ Jesow, Neri $>$ Neryjow, Melchi $>$ Melchijow. It must be pointed out that some adjectives in the material analysed occur in a number of variant forms, which is connected with the various methods of morphological adaptation of some names, e.g. Abelowy// Ablowy, Abiaszowy// Abiowy, Alfeuszow, -y// Alfeow, Kajfaszow// Kajafaszow, Naggow// Naggeow, Publiuszow// Popliow, Salow// Saleow, Tymeuszow// Tymeow, Appiuszowy// Appiowy, Festusowy// Festowy, Narcysowy// Narkissowy, Falegow, -y// Falekowy, Arfaksadow, -y// Arfakadowy, Jaretow// Jaredow, $-y$, Zebedeuszow, $-y / /$ Zebedeowy.

Forms with the suffix -in are also found among possessive adjectives excerpted from the Polish translations of the New Testament. They are not as numerous as the derivatives in -ow; what is more, their occurrence (only in the short inflection) is limited to the older texts. As few as 9 masculine and 2 feminine names form adjectives in -in. From masculine anthroponyms are formed: Joannin (<Jan) Mu, Jannin (<Janna) Mu, Judzin (<Juda) Cz, Kefin (<Kefa) Cz, W, Melchin (<Melcha) Mu, Salin (<Sala) Mu, Semein (< Semea) Mu, Stefanin (< Stefana) Brz, Cz, Tarzyn (< Tara) Mu, whereas derivatives such as Herodyjadzin (<Herodyjada) Mu, Sarzyn (<Sara) $M u, C z$ are derived from feminine names. The distribution of adjectives in -in is the following: $M u$ (8 forms), $C z$ (3), $B r z(1), W(1)$. It is worth noting that the presence of

16 E. Breza, Odmiana nazw własnych w Nowym Testamencie Biblii Wujka i Biblii Tysiaclecia, [in:] Biblia a kultura Europy, ed. M. KAMIŃsKA, E. MAŁEK, vol. I, Łódź 1992, p. 152-159 (154).

17 M. MALEC, Imiona chrześcijańskie w średniowiecznej Polsce, Kraków 1994; R. ZARĘBSKI, Nazwy osobowe..., p. 108-147. 
adjectives formed with -in only in these translations proves that there are strong philological ties among them, in particular between $\mathrm{Mu}, \mathrm{Cz}$ and $\mathrm{Brz}^{18}$.

Derivatives in -in were formed solely from nouns ending in $-a^{19}$. Therefore, their presence in the old translations was determined by the various methods of morphological adaptation of foreign names. This phenomenon may be illustrated

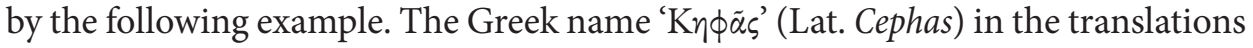
analysed is characterized by a broad array of variant shapes, e.g. Cefas, Kefas, Kefasz, Kifas// Kiefa, Kefa, Kifa. If the name was adapted as consonant-final in a given translation, the possessive adjective was formed with -ow, in accordance with the morphonological rules of distribution. On the other hand, variants with a word-final vowel took the suffix -in.

In the material examined, a few adjectival forms with possessive meaning are formed with the suffix $-s k{ }^{20}$, e.g. judzki $(<J u d a)$, zabulonski ( $<$ Zabulon), neftalimski $(<$ Neftalim). Their presence was limited almost exclusively to old translations. In some contemporary translations the adjective judzki appears $(D b, D n, P r, D)$.

The register of all possessive adjectives formed from proper personal names in the Polish translations of the New Testament is as depicted above. Forms in -ow constitute the majority of the analysed examples. This is mainly due to the fact that the dominant part of the New Testament names were adapted into to the Polish masculine declension. Adjectives in -ow were formed precisely from nouns that belonged to the non-palatal and palatal masculine paradigms. The use of adjectival derivatives in old translations results not only from the linguistic reasons which determined the huge popularity of the adjectival possessive attribute in $15^{\text {th }}-18^{\text {th }}$ century Polish. It also indicates the high linguistic consciousness of the translators $^{21}$. This is reflected in the stylistic shape of the excerpted texts, because it shows how the authors attempted to make their translations more consistent with the language of their times instead of blindly following the authority of the base text.

As regards the usage of possessive adjectives in the $20^{\text {th }}$-century translations of the New Testament, it has already been said above that they occur fairly infrequently. There are only 7 recorded forms in -ow (y) in BT: Mojżeszowy (used 8 times), Janowy (7), Chrystusowy (2), Dawidowy (2), Jakubowy (2), Salomonowy (1), Szymonowy (1). A similar situation is to be found in other contemporary translations. Moreover, if one compares the use of possessive adjectives in BT (first published in 1965) and the ecumenical translation $(E)$ from 2001, the difference in the use of relational adjectives is noticeable, in spite of the short lapse of time between the two translations. Where $B T$ uses an adjectival derivative, the authors of $E$ use genitival

\footnotetext{
${ }_{18}$ More general linguistic and stylistic research also confirms this.

19 J. Łoś, op. cit., p. 36; S. SZlifersztejnowa, op. cit., p. 93.

20 J. Łoś, op. cit., p. 84-85; S. SZLIFERSZTEjNOWA, op. cit., p. 103.

${ }^{21}$ In her study of the onomastics of the Psalterium Sinaiticum, T. Friedelówna considers the use of possessive adjectives formed from personal names an indication of the authors' derivational inventiveness (cf. T. Friedelówna, op. cit., p. 24).
} 
structures, e.g. potomstwo Abrahamowe BT / Abrahama E (Hebr 2, 16), w krużganku (...) Salomonowym BT / Salomona E (Act 3, 11), w prawie Mojżeszowym, prawa Mojżeszowego BT / Mojżesza E (Lc 2, 22; Io 7, 23; Act 13, 39; 28, 23), chrzest Janowy BT / Jana E (Mc 11, 30; Lc 7, 29; 20, 4; Io 5, 36), Jakubowy BT / Jakuba E (Mc 5, 37), potomstwo Dawidowe BT / Dawida E (Io 7, 42), Szymonowego BT / Szymona E (Mc 1, 16), Ducha Chrystusowego BT/ Chrystusa E (Rom 8, 9), córka Syjońska BT / Syjonu E $(\mathrm{Mt} 21,5)^{22}$. However, that the possessive adjectival attribute goes out of use may depend not only on the linguistic factors reflected in the developmental trends of Polish, but also on extralinguistic factors. The point is that the text is modernised so as to make its language close to the reality of contemporary Polish. At the same time, the translators of the latest versions of the New Testament use archaic adjectival forms to show their respect for the traditional biblical style, within which the forms in question were not anything peculiar ${ }^{23}$. The presence of possessive adjectives in the $20^{\text {th }}$-century $D b$ translation, more noticeable than in the other contemporary translations of the New Testament, must be ascribed precisely to the continuation of the Polish biblical style. It is especially visible in the ways of expressing family relations, e.g. Maria Józefowa (P, Br), Maria Jakubowa (P, Br), Juda// Judasz Jakubowy (Pr), Jakub Alfeuszowy (Pr).

As regards the stylistic value of adjectival possessive derivatives and their impact on the stylistic development of the New Testament translations under analysis, it is important to note the hesitation of certain translators, inferrable from various commentaries or marginal glosses. Namely, alternant forms of some anthroponyms are found in a few Middle Polish translations. Two types of translators' hesitation can be noted. The more frequent one consists in the presence of an adjectival derivative in the main text and the base name of this derivative in the mar$\operatorname{gin}^{24}$, e.g.: Abrahamow// ${ }^{*}$ Abraham $(\operatorname{Lc} 3,34)$, Addow $/ /{ }^{*}$ Addi $(\operatorname{Lc} 3,28)$, Aminadabow// ${ }^{\star}$ Aminadab (Lc 3, 33), Amosow// ${ }^{\star}$ Amos (Lc 3, 25), Arfaksatow// ${ }^{\star}$ Arfaksat (Lc 3, 36), Aramow// ${ }^{\star}$ Aram $(\operatorname{Lc} 3,33)$, Boozow// ${ }^{\star}$ Booz $(\operatorname{Lc} 3,32)$, Dawidow// ${ }^{\star}$ Dawid (Lc 3, 31), Enosow// ${ }^{\star}$ Enos (Lc 3, 38), Esromow// ${ }^{\star}$ Esrom (Lc 3, 33), Falekow// ${ }^{\star}$ Falek (Lc 3,35), Faresow// ${ }^{*}$ Fares $(\operatorname{Lc} 3,33)$, Herow// ${ }^{*} \operatorname{Her}(\operatorname{Lc} 3,28)$, Helijakimow// Helijakim (Lc 3, 30), Heberow// Heber (Lc 3, 35), Helijezerow// Helijezer (Lc 3, 29), Helmadamow// Helmadam (Lc 3, 28), Izaakow//Izaak (Lc 3, 34), Jannin// *anna (Lc 3, 24), Jaretow// *Jaret (Lc 3, 37), Jesow// ${ }^{*}$ Jeso $(\operatorname{Lc} 3,29)$, Jonamow// ${ }^{\star}$ Jonam $(\operatorname{Lc} 3,30)$, Joramow// Joram $(\operatorname{Lc} 3,29)$, Jozefow// ${ }^{\star} \operatorname{Jozef}(\operatorname{Lc} 3,23 ; 3,24 ; 3,26 ; 3,30)$, Judow// ${ }^{*}$ Juda $(\operatorname{Lc} 3,26 ; 3,30)$, Kainanow// ${ }^{\star}$ Kainan $(L c 3,36 ; 3,37)$, Kosamow// ${ }^{*}$ Kosam (Lc 3, 28), Lamechow// ${ }^{\star}$ Lamech (Lc 3, 36), Maleleelow// ${ }^{\star}$ Maleleel (Lc 3, 37), Matattyjaszow// ${ }^{\star}$ Matattyjasz (Lc 3, 25), Matuzalow// ${ }^{\star}$ Matuzala $(\operatorname{Lc} 3,37)$, Melchin// ${ }^{*}$ Melchi $(\operatorname{Lc} 3,28)$, Meleow// ${ }^{\star}$ Melea $(\operatorname{Lc} 3,31)$,

22 The opposite situation - a gen. sg. form in BT versus a possessive adjective in E, e.g. Dawida BT / $z$ miasta Dawidowego E (Lc 2, 4), Cezara BT / $z$ domu cesarskiego E (Phil 4, 22) - appears occasionally.

${ }^{23}$ D. BieŃKowsKa, op. cit., p. 30-41.

${ }^{24}$ Forms excerpted from marginal glosses are preceded with the sign *. 
Menamow// ${ }^{\star}$ Menam $\left(\right.$ Lc 3, 31), Natanow// ${ }^{*}$ Natan $(L c 3,31)$, Naggow// ${ }^{*}$ Nagge (Lc 3, 25), Nachorow// ${ }^{*}$ Nachor (Lc 3, 34), Naassonow// ${ }^{*}$ Naasson $\left(\right.$ Lc 3, 32), Naumow// ${ }^{*}$ Naum (Lc 3, 25), Obedow// ${ }^{\star}$ Obed $(\mathrm{Lc} 3,32)$, Pawłowy $/{ }^{*}$ Pawet $\left(1\right.$ Cor 16, 21), Resyjow// ${ }^{\star}$ Resyja $(\operatorname{Lc} 3,27)$, Ragawow// ${ }^{*}$ Ragaw $(\operatorname{Lc} 3,35)$, Semow// ${ }^{\star S e m}(\operatorname{Lc} 3,36)$, Semein// ${ }^{\star}$ Semej (Lc 3, 26), Symeonow// Symeon (Lc 3, 30), Setow// ${ }^{*}$ Set $($ Lc 3, 38), Saruchow// *Saruch (Lc 3, 35), Tarzyn// ${ }^{\star T a r r a}(\operatorname{Lc} 3,34)$, Zorobabelow// ${ }^{*}$ Zorobabel $(\operatorname{Lc} 3,27)$, W: Barachijaszowego (G. m. sg.)// *Barachijasz (Mt 23,35). The second one, found more rarely, is the opposite situation - a name in the nom. sg. or (less frequently) in an oblique case is used in the main text, whereas a possessive adjective formed from it is noted in the margin, e.g. Mu: Andrzej// ${ }^{\star}$ Andrzejow (Io 1, 44), Helijasz// * Helijaszowy (Rom 11, 2), Jozef/ $/{ }^{\star}$ Jozefow (Act 7, 14), W: Bosor// ${ }^{\star}$ Bozorow $(2 \mathrm{Pe} 2,15)$.

The material depicted above was only found in two $16^{\text {th }}$-century translations. Numerous marginal glosses were used by the translator of the $M u$ text, based on the Greek original and its translation $(W)$, whose base was the Vulgate ${ }^{25}$. The translators' hesitation which can be observed here testifies not only to their philological training, but also to a high linguistic consciousness, which leaves its mark on the stylistic layer of the translation. The forms which got marginalised in the old texts provide a valuable source for understanding the philological techniques of the former Biblicists. They show the process of looking for a compromise between the linguistic layer of the basis of the translation and the language of the translation itself.

The analysis of possessive adjectives in old and contemporary Polish translations of the New Testament leads to a number of conclusions of a linguistic and stylistic nature. It is worth repeating once again that Old Polish and Middle Polish translations abound in possessive derivatives, which was in accordance with the spirit of the Polish of those times. That adjectival attributes go out of use in the newer versions of the New Testament is a sign of the processes that are taking place in contemporary Polish.

It is instructive to analyse the category under discussion in a wider Slavic context. $15^{\text {th }}-17^{\text {th }}$ century Polish continued the state attested in the translations of the Biblical books into Old Church Slavonic. This can be demonstrated by even a cursory look at the lexicographical material. A wide range of examples belonging

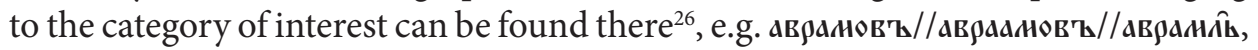

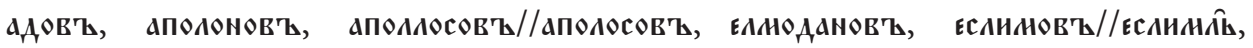

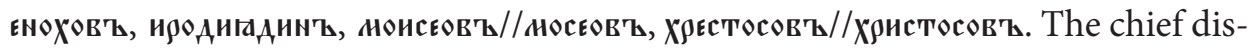

${ }_{25}$ Among the Polish linguists and biblical scholars the philological training of the translators of $M u$ and $W$ is widely known and valued (cf. M. Kossowska, Biblia w języku polskim, vol. I-II, Poznań 1968-1969).

${ }^{26}$ Examples from: Slovník jazyka staroslovènského. Lexicon linguae palaeoslovenicae, ed. J. KuRz, Z. HAupTOvÁ, vol. I-IV, Praha 1958-1997 as well as Indeks a tergo do materiałów do słownika I. I. Srezniewskiego, ed. A. OвRĘBSKA-JabŁońsKa et al., Warszawa 1968. 
crepancies between the Old Church Slavonic and Old Polish translations concern the use of different suffixes, e.g. Мєлєанъанов' - Melein, сттєфаниновъъ//сттєфанов' - Stefanin. That being said, disparities of this kind also exist among the particular Old and Middle Polish translations, e.g. Semeiow//Semein, Stefanow//Stefanin.

The use of deanthroponymic possessive adjectives influences the stylistic layer of the analysed texts, as it may evoke changes in the set of names used in particular texts ${ }^{27}$. If we take a closer look at possessive adjectives in the corpus of $20^{\text {th }}$ century translations, we can notice how various methods of translation clash. On the one hand, using archaic derivatives may be a sign of deep respect for the tradition of translation; but if used too often, they show that the translator is enslaved by this tradition, as it is the case in $D b$. On the other hand, the non-use of adjectival possessive attributes testifies to the commendable process of modernization of the biblical language; however, it may turn out incompatible with the stylistic habits of the reader. Once again, translating biblical texts proves to be a challenging task: it is difficult to reach a compromise that would satisfy theologians, biblists, linguists and the remaining recipients.

\begin{abstract}
The study focused on possessive adjectives derived by means of the suffixes -ow $(y)$, -in, -sk-formed from proper personal names in old and contemporary translations of the New Testament. Adjectival derivatives have been excerpted from 15 full and 6 incomplete translations of the New Testament, which date back to the $16^{\text {th }}, 17^{\text {th }}$ and $20^{\text {th }}$ century. These translations differ in methods of translation (loose and word-for-word; philological, interlinear, ecumenical, dynamic and artistic) and its basis (Greek original or Latin Vulgate). The comparative analysis of old and contemporary translations shows that possessive adjectives, though used frequently in former times, are now going out of use and the substantival genitival attribute is taking their place. This phenomenon is reflected in processes linked with the development of the Polish language. Moreover, tracking the use of the type of adjectives analysed can be used to distinguish various methods of translation. The use of possessive adjectives in contemporary texts suggests respect for the tradition of translation, whereas the failure to use them - the modernization of Polish.
\end{abstract}

Rafał Zarębski

Katedra Historii Języka Polskiego

Wydział Filologiczny

Uniwersytet Łódzki

al. Kościuszki 65

90-514 Łódź, Polska

rafzar@interia.pl

27 Cf. O. Odelain, R. Seguineau, Dictionnaire des noms propres de la Bible, Paris 1978. 